\title{
MENANAMKAN KEMUHAMMADIYAAN PADA MAHASISWA NON-MUSLIM MELALUI PENDIDIKAN MULTIKULTURAL DI UNIVERSITAS MUHAMMADIYAH KUPANG
}

\author{
EMPHASIZING MUHAMMADIYAH TO NON-MUSLIM STUDENTS THROUGH \\ MULTICULTURAL EDUCATION AT MUHAMMADIYAH UNIVERSITY OF KUPANG
}

\author{
Syahrul \\ Fakultas Keguruan dan Ilmu Pendidikan, Universitas Muhammadiyah Kupang \\ email: syahrulkadir7@gmail.com
}

Naskah Diterima: 22 Agustus 2019; Direvisi: 13 September 2019; Disetujui: 12 Agustus 2020

\begin{abstract}
The purpose of this study was conducted to determine the emphasis of Muhammadiyah and cultural propaganda to non-Muslim students through multicultural education. The study uses a qualitative method and purposive sampling to select the subjects, namely non-Muslim students, lectures of multicultural education, and AIK. Data were collected through interviews, observation, file notes, and analyzed in one circle among data collection, categories, reading, memoing, description, classification, interpretation, and visualization. The result is (1) after applying four multicultural education approaches, such as contribution, additive, transformation, and social action approaches, the values of Muhammadiyah can be emphasized and do not undermine their non-Muslim religious. Furthermore, they realize that Muhammadiyah is an Islamic organization that is inclusive and pluralist. On the other hand, (2) cultural and lectures use community propaganda as a learning strategy to explain the values of Muhammadiyah to be accepted by non-Muslim students.
\end{abstract}

Keywords: Muhammadiyah; Multicultural education; Non-Muslim students

\begin{abstract}
Abstrak
Tujuan penelitian ini adalah untuk mengetahui penanaman kemuhammadiyahan dan dakwah kultural Muhammadiyah pada mahasiswa non-Muslim melalui pendidikan multikultural. Penelitian ini menggunakan metode penelitian kualitatif dengan penentuan subjek purposive sampling yang terdiri dari mahasiswa non-Muslim, dosen pendidikan multikultural, dan dosen AIK. Data penelitian dikumpulkan melalui wawancara, observasi, dan catatan lapangan yang dianalisis dengan teknik lingkaran yang bergerak di antara pengumpulan data, pengorganisasian data, pembacaan, memoing, deskripsi, klasifikasi, penafsiran, penyajian dan visualisasi. Hasil penelitian ini menunjukkan bahwa (1) setelah diterapkan empat pendekatan pendidikan multikultural, yaitu pendekatan kontribusi, aditif, tranformasi dan aksi sosial, maka nilai-nilai kemuhammadiyaan pada mahasiswa non-Muslim dapat ditumbuhkan dan tidak melunturkan keyakinan mereka terhadap agamanya. Selanjutnya mereka menyadari bahwa Muhammadiyah adalah sebuah organisasi Islam yang bersikap inklusif dan pluralis. Selain itu, (2) dakwah kultural dan komunitas digunakan oleh dosen sebagai strategi pembelajaran untuk menjelaskan nilai-nilai kemuhammadiyaan agar bisa diterima oleh mahasiswa non-Muslim.
\end{abstract}

Kata Kunci: Mahasiswa non-Muslim; Muhammadiyaan; Pendidikan multikultural 


\section{PENDAHULUAN}

Penanaman kemuhammadiyaan pada mahasiswa non-Muslim di UMK (Universitas Muhammadiyah Kupang) telah lama diterapkan melalui mata kuliah AIK (Al-Islam Kemuhammadiyaan), namun dalam proses implementasinya sering dikeluhkan oleh mahasiswa non-Muslim karena mereka seolah dipaksakan untuk memahami ke-Islaman daripada ke-Muhammadiyah (Arifin, 2015). Ini disebabkan karena di dalam proses penerapannya tersebut, dosen AIK dianggap gagal karena tidak pro terhadap non-Muslim. Dosen AIK cenderung menggeneralisir bahwa mahasiswa yang diajarnya adalah semua sama, sehingga kebijakan khusus untuk mereka yang non-Muslim diabaikan (Efendi \& Suswanta, 2017). Mereka terkadang mengeluh karena merasa seolah diislamkan, padahal mereka masuk di UMK bukan untuk belajar Islam, tetapi ingin belajar dan ahli di jurusan yang mereka pilih. Tidak jarang dari mahasiswa nonMuslim malas mengikuti mata kuliah AIK dan Bahasa Arab dikarenakan paksaan struktural. Menurut mereka, mengikuti kelas AIK dan Bahasa Arab adalah dalam kondisi keterpaksaan, hanya saja karena mata kuliah ini adalah wajib untuk semua mahasiswa, sehingga mereka mengikutinya dalam kondisi yang tidak nyaman (B. Nelson, personal communication, July 29, 2019).

Pemilihan materi perkuliahan AIK yang tidak selektif, yaitu memilih materi yang sesuai untuk mahasiswa non-Muslim tidak dilaksanakan, sehingga banyak di antara mahasiswa non-Muslim merasa tertekan dalam proses pembelajaran. Menurut mereka materi perkuliahan lebih cenderung pada pemahaman hadis-hadis, ayat-ayat Alquran, rukun Islam, dan tata-tata cara beribadah (Efendi \& Suswanta, 2017). Banyak juga mahasiswa nonMuslim merasa tidak perlu mengikuti evaluasi AIK dan Bahasa Arab karena beberapa soal UAS lebih cenderung menguji pemahan keIslaman layaknya mahasiswa Islam yang diuji keimanannya, tafsir Alquran dan Hadis, serta ajaran Islam lainnya. Oleh karena itu, banyak mahasiswa non-Muslim malas mengikuti mata kuliah AIK, ini dibuktikan dari daftar hadir dan hasil wawancara (S. S. Djou, personal communication, July 30, 2019).
Banyak juga mahasiswa non-Muslim yang mempertanyakan "apakah kami diperbolehkan untuk tidak mengikuti mata kuliah AIK dan Bahasa Arab?" Pertanyaan ini membuat dilema bagi para dosen karena mata kuliah AIK dan Bahasa Arab adalah dari universitas bukan dari program studi (Arifin, 2015). Sehingga melihat persoalan ini, Banks menawarkan kurikulum pendidikan multikultural yang nantinya mata kuliah AIK bisa dilebur menjadi sebuah kesadaran multikultural di dalam setiap perkuliahan melalui mata kuliah pendidikan multikultural (J. A. Banks, 2017; Demir \& Yurdakul, 2015; Gorski, 2009). Tidak hanya itu, di dalam pendidikan multikultural, toleransi beragama khususnya keislaman dalam bermasyarakat dapat diperkenalkan kepada mahasiswa nonMuslim (Altaş, 2015; Gökarıksel \& Secor, 2015). Hal ini sejalan dengan cita-cita UMK dalam menerapkan pendidikan multikultural sebagai Dakwah Kultural Muhammadiyah untuk mahasiswa non-Muslim (Z. Wula, personal communication, June 15, 2019).

Di beberapa Universitas Muhammadiyah di Indonesia memiliki mahasiswa non-Muslim, tetapi di UMK terdapat keunikan tersendiri dibandingkan dengan yang lainnya karena jumlah mahasiswa non-Muslim di UMK lebih banyak daripada yang Muslim, yaitu mahasiswa non-Muslim $71 \%$ sedangkan yang Muslim hanya 29\% (Z. Wula, personal communication, June 15, 2019). Dengan melihat perbandingan tersebut, pembelajaran AIK pada mahasiswa non-Muslim perlu dipertimbangkan. Oleh karena itu, memberikan pemahaman kemuhammadiyaan pada mahasiswa nonMuslim melalui pendidikan multikultural sangat penting (Bauman et al., 2019; Wibowo, 2018). Ini sejalan dengan yang dimaksudkan oleh Syamsuddin bahwa semakin berkembangnya organisasi Muhammadiyah maka dibutuhkan kesadaran multikulturalisme di setiap lembaga pendidikan dan amal usaha lainnya (Syamsuddin, 2018).

Hasil penelitian Efendi dan Suswanta di UMK menunjukkan bahwa pendidikan multikultural sangat penting karena banyak di antara mahasiswa non-Muslim yang merasa belajar AIK dan Bahasa Arab adalah sebuah proses Islamisasi (Efendi \& Suswanta, 2017). Oleh 
karena itu, melalui pendidikan multikultural tujuan dan cita-cita Muhammadiyah dapat diperkenalkan kepada mahasiswa non-Muslim. Dengan cara itu, pendidikan multikultural di UMK dimaksudkan untuk menanamkan kesadaran pluralis dan inklusif pada semuah mahasiswa (Gökarıksel \& Secor, 2015; Mareş, 2014). Ini dilakukan dengan cara menerapkan metode pembelajaran yang lebih menghargai perbedaan agama, ras, etnis, suku, bahasa dan perbedaan lainnya karena di dalam pendidikan multikultural, mahasiswa cenderung diarahkan pada kesadaran individu dalam menerima perbedaan (Paul-Binyamin \& Haj-Yehia, 2019; Szelei et al., 2019). Itulah yang harus dilestarikan, diterima, dan dihargai karena pada hakikatnya manusia tidak diciptakan seragam (Mareş, 2014). Mahasiswa juga harus menyadari bahwa perbedaan itulah yang menjadikan manusia sebagai makhluk sosial yang saling membutuhkan satu dengan yang lainnya. Jika manusia dipaksakan untuk sama atau seragam maka tidak akan ada yang namanya hubungan sosial dalam masyarakat yang ada hanya sekelompok orang-orang pasif (Savage, 2019; Schoorman \& Bogotch, 2010).

Penelitian yang mengkaji multikulturalisme di UMK telah dilakukan oleh beberapa peneliti sebelumnya, seperti yang telah dilakukan oleh Efendi dan Suswanta, namun dalam penelitian tersebut hanya dapat mengungkap gambaran umum tentang multikultural di UMK (Efendi \& Suswanta, 2017). Terdapat juga persoalan-persoalan kompleks yang telah mereka uraikan dalam penelitiannya, yaitu penerapan pembelajaran AIK dan Bahasa Arab yang seolah tidak mencerminkan makna dari multikulturalisme. Penelitian ini juga dilakukan untuk mengkaji persoalan-persoalan yang tidak pro terhadap multikulturalisme, dan mengungkap peristiwa-peristiwa penting di dalam menanamkan kemuhammadiyaan melalui pendidikan multi-kultural. Sehingga penelitian ini mengkaji tentang bagaimana penanaman ke-muhammadiyaan di dalam pendidikan multi-kultural khususnya pada mahasiswa non-Muslim di UMK.

\section{METODOLOGI}

Jenis penelitian ini adalah penelitian kualitatif yang berusaha memaknai subjek mahasiswa non-Muslim dalam proses pembelajaran yang multikultural di Program Studi Pendidikan Sosiologi, UMK. Tujuan penelitian ini adalah untuk mengetahui bagaimana penanaman kemuhammadiyaan dan dakwah kultural Muhammadiyah pada mahasiswa non-Muslim melalui pendidikan Multikultural. Oleh karena itu, peneliti menggunakan metode penelitian kualitatif yang didasarkan pada interpretasi serta pemaknaan data (verstehen) (Berger \& Luchmann, 2019). Pemilihan lokasi penelitian di UMK karena sebagai kampus Islam UMK justru didominasi oleh mahasiswa non-Muslim yaitu 71\%, sedangkan Islam 29\%. Di sisi lain, pemilihan lokasi penelitian berdasarkan visi UMK yaitu berwawasan multikultural. Pemilihan informan dengan purposive sampling di antaranya mahasiswa non-Muslim dan dosen. Teknik pengumpulan data yang digunakan dalam penelitian ini adalah observasi digunakan untuk mengamati tingkah laku aktual mahasiswa nonMuslim, yaitu peneliti melakukan observasi di dalam kelas untuk melihat bagaimana proses pembelajaran multikultural berlangsung. Wawancara digunakan peneliti bersifat semi terstruktur, artinya sebelumnya peneliti tidak menyiapkan daftar pertanyaan secara terperinci, melainkan sekedar menyiapkan poin-poin yang hendak ditanyakan pada mahasiswa nonMuslim. Catatan lapangan dilakukan dengan membuat catatan dalam bentuk deskriptif berupa peristiwa pembelajaran di dalam kelas dan gambaran kegiatan pembelajaran. Analisis data dilakukan dalam bentuk lingkaran analisis, yaitu peneliti bersinggungan dengan beberapa saluran analisis dan berputar dan terus berputar, di antaranya: mengorganisasikan data, pembacaan, memoing, deskripsi, klasifikasi, penafsiran, penyajian dan visualisasi (Creswell, 2013).

\section{HASIL DAN PEMBAHASAN}

Pemilihan tema-tema kemuhammadiyaan di dalam pendidikan multikultural di UMK dilakukan secara selektif, karena yang di hadapi di dalam kelas perkuliahan adalah mayoritas mahasiswa beragama Kristen. Hampir di setiap kelas kita hanya menemukan sekitar 5-10\% yang beragama Islam. Sehingga pemilihan tema yang berkaitan dengan Muhammadiyah adalah sifatnya lebih pluralis. Secara teoritis, UMK berpandangan bahwa pluralitas agama adalah 
realitas objektif dalam kehidupan sosial keagamaan di Kota Kupang. Karena penolakan terhadap pluralitas agama akan berdampak pada kegagalan dakwah Muhammadiyah dan amal usaha di bidang pendidikan di Nusa Tenggara Timur (NTT). Di sisi lain, umat Islam yang minoritas di NTT menjadi salah satu alasan pentingnya pendidikan multikultural di UMK. Oleh karena itu, UMK menerima pluralitas agama tetapi menolak pluralisme yang mengarah pada sinkretisme, sintesisme, dan relatifisme. Sehingga, mahasiswa Muslim dan non-Muslim diajak untuk memahami pluralitas agama, toleransi dan koeksistensi (hidup berdampingan secara damai) dengan tetap meyakini kebenaran agamanya masing-masing. Lebih jauh lagi, pada Gambar 1. Dapat dilihat skema proses penanaman kemuhamadiyaan pada mahasiswa non-Muslim di UMK.

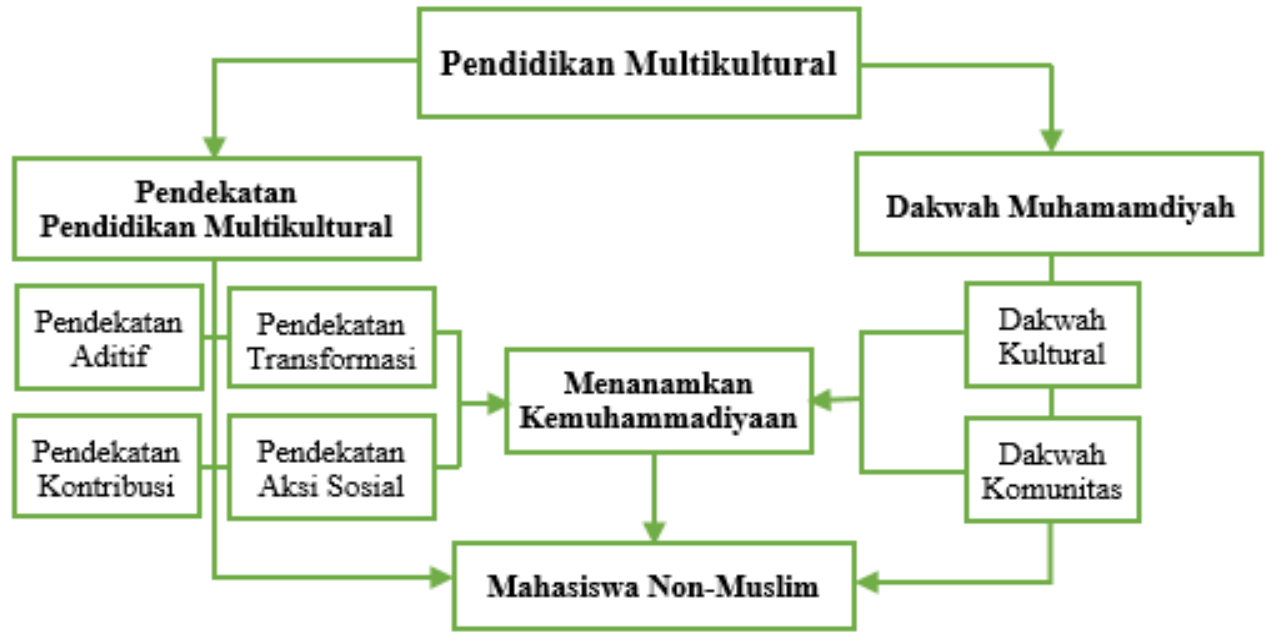

Gambar 1. Skema penanaman kemuhammadiyaan pada mahasiswa non-muslim melalui Pendidikan multikultural

Dakwah kultural Muhammadiyah di UMK memiliki dua bagian, yaitu dakwah kepada mahasiswa Muslim dan non-Muslim. Pada prinsipnya, penerapan dakwah ini berbasis pada konsep pendidikan multikultural demi menghindari adanya hegemoni terhadap mahasiswa. [1] Dakwah kultural kemuhammadiyaan pada mahasiswa Muslim di UMK pada prinsipnya lebih mengedepankan ajaran Islam murni dan pengenal Muhammadiyah sebagai organisasi Islam karena masih banyak di antara mahasiswa yang belum mengenal Muhammadiyah, bahkan Muhammadiyah masih dianggap sebagai ajaran sesat karena ajaran agama Islam yang mereka peroleh secara kebudayaan berbeda dengan yang diperoleh dari lembaga Muhammadiyah. Namun dalam kajian ini lebih fokus pada mahasiswa non-Muslim, yaitu: [2] Dakwah kultural Muhammadiyah pada mahasiswa nonMuslim yang pada prinsipnya lebih mengedepankan pada ajaran Islam secara universal dan pluralitas dalam Muhammadiyah untuk menghilangkan prasangka negatif misalnya Islamofobia. Oleh karena itu, dalam menanamkan kemuhammadiyaan pada mahasiswa non-Muslim di UMK digunakan pendekatan multikulturalisme.

\section{Menanamkan Kemuhammadiyaan pada Mahasiswa Non-Muslim Melalui Pendekatan Pendidikan Multikultural}

Menanamkan kemuhammadiyaan pada mahasiswa non-Muslim di UMK terlebih dahulu ditumbuhkan kesadaran pluralisme kepada mereka melalui pendidikan mutikultural. Dosen yang mengampuh mata kuliah Pendidikan Multikultural juga telah menyadari dan memahami pentingnya nilai-nilai yang menopang budaya plural. Nilai-nilai itu telah dikembangkan menjadi bagian dari budaya kampus UMK. Artinya, UMK tidak hanya bisa dikonsep sebagai lembaga pendidikan untuk menguasai pengetahuan dan pengembangan potensi dalam perspektif monokultur karena UMK sudah menjadi arena multikulturalis bagi mahasiswa. Ini diperkuat di dalam visi UMK. Oleh karena itu, dosen menanamkan kemuhammadiyaan di dalam pembelajaran Pendidikan Multikultural di UMK dengan menggunakan beberapa jenis pendekatan. 


\section{Menanamkan Kemuhammadiyaan melalui Pendekatan Kontribusi}

Pendekatan kontribusi digunakan untuk mengintegrasikan materi etnis ke dalam pembelajaran multikultural, misalnya memasukkan tokoh Muhammadiyah yaitu KH. Ahmad Dahlan serta sejarah dan kontribusi perjuangan Muhammadiyah dalam kemerdekaan Indonesia. Ini dilakukan dengan memberikan kesaksian dan pembuktian yang dilakukan Muhammadiyah di antaranya melalui upaya terhadap penguatan konsep dalam tafsir dan penjabaran nilai-nilai Pancasila dengan merujuk kepada Alquran dan Sunnah, misalnya toleransi antara umat beragama dalam penjabaran dan pengalaman sila Ketuhanan yang Maha Esa. Penguatan konsep akhlak dan keadaban dalam penjabaran sila kemanusiaan yang adil dan beradab, penguatan konsep persaudaraan antara sesama warga negara sebagai pengayaan atas Sila Persatuan Indonesia. Dengan penjabaran ini, pendidikan multikultural dapat mengenalkan pandangan Muhammadiyah yang rahmatan lil alamin (universal) dan sejalan dengan nilai-nilai Pancasila, sehingga mahasiswa UMK dari kalangan non-Muslim benar-benar memahami bahwa ajaran Islam dan keberadaan umat Islam di NTT tidak mengancam mereka, bahkan sebaliknya sangat menghormati keberadaan non-Muslim di UMK.

Di dalam proses pembelajaran multikultural juga dimasukkan materi-materi kemuhammadiyaan yang berkaitan dengan interaksi sosial antara umat Islam dengan nonIslam. Misalnya, memberikan pemahaman kepada mahasiswa non-Muslim bahwa Islam adalah agama yang memiliki kemampuan hebat untuk berinteraksi dengan segala macam umat manusia sepanjang masa meskipun itu adalah kelompok-kelompok yang memerangi orangorang Islam, seperti kaum Yahudi, Nasrani, kaum fakir, bahkan yang berkaitan dengan ras yaitu berkulit hitam atau putih, dan lain sebagainya. Penanaman kemuhammadiyaan yang moderat pada mahasiswa non-Muslim di UMK dilakukan dengan kontribusi teori-teori interaksi sosial Muhammadiyah ke dalam pembelajaran multikultural yang dilakukan dengan metode sebagai berikut:
Pertama, metode pengakuan perbedaan dilakukan dengan cara menanamkan kepada mahasiswa non-Muslim bahwa Muhammadiyah mengakui perbedaan di antara manusia dalam hal beragama karena semua itu terjadi atas kehendak Tuhan. Ini dapat dilihat dari hasil wawancara dengan salah satu mahasiswa non-Islam,

Kami sebagai mahasiswa non-Muslim sudah mendapatkan hak kami, contohnya seperti dosen memperlakukan kami yang non-Muslim sama saja seperti mahasiswa Muslim, tidak membedakan antara yang Muslim dan yang non-Muslim. Berdasarkan pengalaman saya dalam proses perkuliahan sangat ditanamkan nilai-nilai multikulturalisme karena dalam proses perkuliahan dosen tidak membedakanbedakan mahasiswa baik dari segi budaya, ras, etnik dan agama (N. Y. Auw, personal communication, July 26, 2019).

Kedua, metode perkenalan dilakukan dengan cara menanamkan kepada mahasiswa non-Muslim bahwa sikap saling mengenal adalah ajaran yang dipegang teguh dalam organisasi Muhammadiyah sekaligus sebuah keniscayaan yang menjadi tuntutan hidup bagi warga UMK. Di samping itu, sikap saling mengenal sebagai upaya mengaktifkan semangat persaudaraan dan kemanusiaan yang sering terabaikan akibat perbedaan agama.

Ketiga, metode hidup berdampingan dilakukan dengan cara menanamkan kepada mahasiswa non-Muslim bahwa di dalam lingkungan UMK terjadi hubungan interaksi sosial yang tidak terwujud damai tanpa adanya sikap toleransi dan pluralisme. Oleh karena itu, sikap toleransi dan pluralisme di UMK diwujudkan melalui interaksi sosial antara dosen dengan mahasiswa. Dari hasil wawancara dengan salah satu mahasiswa mengungkapkan bahwa dosen memberikan materi tentang interaksi sosial yang berdasarkan pada nilainilai multikulturalisme, seperti;

Lingkungan kampus UMK sangat bagus dan kami sebagai mahasiswa Nasrani sangat senang berada di kampus UMK karena tidak ada rasa intimidasi bagi kami. Untuk saat ini, lingkungan kampus sangat aman dan damai karena tidak ada keributan-keributan yang terjadi di 
kampus UMK ini dan itu yang membuat kami sangat nyaman. Bagi saya, kampus Muhammadiyah Kupang memiliki nilai toleransi sangat tinggi dan sangat menonjol. Ini yang membuat kami di Prodi Pendidikan Sosiologi tidak pernah saling memfitnah atau saling mencela satu sama lain karena itu yang ditanamkan oleh dosen-dosen kami di UMK. Di UMK saat ini rasa persaudaraan yang sangat tinggi baik itu pada mahasiswa ataupun dosen, dan nilai-nilai sosial yang sedang di terapkan oleh dosen di lingkungan kampus sangat tepat karena dari situlah timbul nilai-nilai multikulturalisme dalam diri kami (A. K. Nautu, personal communication, July 20, 2019).

Keempat, metode tolong-menolong dilakukan dengan cara menanamkan kepada mahasiswa non-Muslim bahwa banyak sekali permasalahan-permasalahan umum yang membentuk pola kebersamaan antara mahasiswa Muslim dengan non-Muslim yang memungkinkan mereka untuk saling tolongmenolong. Selanjutnya, tolong-menolong ini dapat dijadikan sebagai landasan untuk hidup bersama dan saling berdampingan di kampus UMK. Salah satu contoh tolong-menolong yang sering ditunjukkan oleh mahasiswa Islam kepada non-Islam adalah membantu dalam menyelesaikan tugas-tugas mata kuliah Bahasa Arab dan Al-Islam Kemuhammadiyaan. Hal ini mereka lakukan dengan alasan;

saudara-saudara saya non-Muslim merasa kesulitan ketika menjawab pertanyaan atau soal-soal ujian mata kuliah AIK dan Bahasa Arab, karena materi dalam mata kuliah itu menyangkut konsep ke-Islaman serta tuntutan untuk menulis, membaca dan menerjemahkan Bahasa Arab. Saya merasa itu terlalu memaksa mereka sehingga saya terdorong untuk membantu (F. Nubatonis, personal communication, July 29, 2019).

\section{Menanamkan Kemuhammadiyaan melalui Pendekatan Aditif}

Pendekatan aditif dilakukan dengan cara menambahkan konsep kemuhammadiyaan ke dalam materi pembelajaran multikultural tanpa harus mengubah struktur aslinya. Pendekatan ini memperkaya materi pembelajaran multikultural dari literatur Muhammadiyah yang dilakukan dengan cara mengajak mahasiswa non-Muslim untuk menilai atau menguji dan kemudian mengapresiasikan cara pandang mereka, tetapi tidak mengubah pemahaman mahasiswa non-Muslim terhadap agamanya masing-masing. Misalnya dari hasil wawancara dengan salah satu mahasiswa non-Muslim mengungkapkan bahwa dosen memberikan materi tentang kemuhammadiyaan yang berdasarkan pada nilai-nilai multikulturalisme, seperti cara mengucapkan salam kepada dosen dan mahasiswa yang berbeda agama, yaitu

Selami ini, setiap kami menyapa teman dan dosen yang beragama Islam kami selalu mengucapkan assalmualaikum, tetapi setelah belajar multikulturalisme kami menyadari bahwa itu adalah keliru karena kami yang mahasiswa Kristen tidak harus mengucap assalamualaikum jika ingin menyapa dosen dan teman yang beragama Islam karena seharusnya kami menggunakan salam dalam agama kami yaitu shalom. Sebaliknya mahasiswa Islam juga tidak harus mengucapkan shalom jika ingin menyapa dosen dan mahasiswa Kristen karena mereka juga memiliki ucapan salam tersendiri yaitu assalamualaikum. Hal ini kami lakukan demi menumbuhkan nilai-nilai multikulturalisme agar kami tidak tercabut dari esensi kami sebagai orang Kristen (N. Y. Auw, personal communication, July 26, 2019).

Uraian di atas mencerminkan adanya multikulturalisme di dalam UMK dengan tujuan untuk mengajarkan nilai-nilai kehidupan Muhammadiyah dengan tidak memaksakan mereka untuk menjadi Islam, sehingga mereka tetap sebagai Kristen yang taat. Gerakan multikulturalisme ini dilakukan di UMK demi mewujudkan warga Muhammadiyah yang berkemajuan untuk membebaskan, memberdayakan, dan memajukan kehidupan umat beragama baik itu Islam maupun non-Islam. Kemuhammadiyaan dihadirkan untuk memberikan jawaban atas problem-problem kemanusiaan berupa kemiskinan, kebodohan, ketertinggalan, dan persoalan-persoalan lainnya 
yang bercorak struktural dan kultural pada masyarakat Islam dan non-Islam di NTT. Menanamkan kemuhammadiyaan di dalam pembelajaran multikultural ini berkomitmen untuk mengembangkan relasi sosial antara mahasiswa Muslim dengan non-Muslim yang berkeadilan tanpa diskriminasi, menjunjung tinggi toleransi dan pluralisme serta membangun keharmonisan sosial di Kampus UMK.

Lebih jauh lagi, penanaman kemuhammadiyaan di dalam pendidikan multikultural terus bergerak dalam mengemban visi UMK yaitu "wawasan multikultural" yang dilakukan melalui dakwah kultural untuk menghadirkan Islam sebagai ajaran yang membangun perdamaian, menghargai pluralitas, menghormati harkat dan martabat mahasiswa non-Muslim, mencerdaskan kehidupan warga UMK, menjunjung tinggi akhlak mulia, dan memajukan kehidupan kampus UMK. Visi UMK tersebut menunjukkan gerakan Muhammadiyah yang dinamis dan progresif dalam menjawab tantangan zaman, tanpa harus kehilangan identitas dan rujukan Islam yang autentik.

\section{Menanamkan Kemuhammadiyaan melalui Pendekatan Transformasi}

Pendekatan transformasi memungkinkan mahasiswa non-Muslim melihat konsep kemuhammadiyah secara kritis. Sementara itu, pendekatan ini menuntut agar mahasiswa nonMuslim memahami secara mendalam konsep kemuhammadiyaan sehingga mereka melahirkan perspektif, kerangka referensi dan gagasan yang memperluas pemahaman mereka tentang kemuhammadiyaan. Oleh karena itu, di UMK diajarkan mata kuliah Pendidikan Multikultural yang di dalamnya memuat tentang kemuhammadiyaan. Di sisi lain, mata kuliah AIK di UMK juga masih tetap diajarkan pada mahasiswa non-Muslim dengan prinsip pendekatan multikulturalisme agar tidak memaksakan ideologi Islam kepada mereka. Hal ini sesuai dengan kritis mahasiswa nonMuslim terhadap mata kuliah AIK di UMK, yaitu;

Proses perkuliahan di UMK belum termasuk dalam kategori multikulturalisme karena dalam mata kuliah AIK masih dominan dalam bentuk kajian Islam, artinya materi yang dibawakan atau disampaikan oleh dosen AIK terlalu tertuju kepada mereka yang menganut agama Islam. sehingga kebanyakan dari kami yang Nasrani mengkritik dosen tersebut karena kami komplen terhadap dosen tersebut dan menganggap dosen terlalu perhatian kepada teman-teman yang Muslim. Kebanyakan kami yang non-Muslim tidak begitu paham terhadap apa yang disampaikan dosen selama perkuliahan. Dalam proses ujian AIK kemari, masih banyak di antara kami yang non-Muslim yang meminta jawaban kepada temanteman Muslim karena tidak begitu paham terhadap soal yang diberikan oleh dosen (S. S. Djou, personal communication, July 30, 2019).

Melihat persoalan tersebut di atas, nampaknya pendekatan transformasi yang telah dilakukan oleh dosen pada mata kuliah Pendidikan Multikultural sangat tepat, yaitu dengan cara transformasi kemuhammadiyaan ke dalam mata kuliah Pendidikan Multikultural. Pembelajaran AIK yang sangat Islamis sering dikeluhkan oleh mahasiswa non-Muslim sehingga tidak jarang dari mahasiswa nonMuslim meminta ke program studi agar mata kuliah ini ditiadakan. Oleh karena itu, di Program Studi Pendidikan Sosiologi, materi kemuhammadiyaan diinternalisasikan ke dalam mata kuliah Pendidikan Multikultural, namun untuk menghilangkan mata kuliah AIK di dalam kurikulum perlu pertimbangan karena itu bukan mata kuliah program studi tetapi mata kuliah umum dari universitas. Di sisi lain, terdapat beberapa dosen AIK yang sudah menyadari bahwa di dalam kelas lebih didominasi oleh mahasiswa non-Muslim, sehingga mereka mengajar AIK lebih cenderung pada kemuhammadiyaan tidak dengan doktrindoktrin Islam.

Oleh karena itu, dalam menghadapi mahasiswa non-Muslim dosen memilih materi pembelajaran yang sifatnya universal. Ada beberapa dosen yang mentransformasikan kemuhammadiyaan ke dalam mata kuliah Pendidikan Multikultural. Misalnya, NTT menghadapi berbagai persaingan peradaban 
yang tinggi akibat adanya Masyarakat Ekonomi Asean. Ini bisa dilihat dari banyaknya investor asing yang masuk ke NTT, perkembangan teknologi di NTT dan juga pertumbuhan agam Islam di NTT yang sangat massif. Oleh karena itu, di dalam pembelajaran ini, dosen menumbuhkan kesadaran pluralisme pada mahasiswa non-Muslim agar mereka siap menghadapi masa depan NTT yang semakin majemuk. Demi masa depan NTT yang lebih majemuk maka diperlukan transformasi mentalitas mahasiswa ke arah pembentukan masyarakat NTT yang pluralis. Manusia yang pluralis dicirikan oleh kapasitas mental yang membedakan dari orang lain seperti keterpercayaan, ketulusan, kejujuran, keberanian, ketegasan, ketegaran, kuat dalam memegang prinsip, dan sifat-sifat khusus lainnya yang melekat dalam dirinya. Sementara itu, nilai-nilai pluralis lainnya yang harus terus dikembangkan adalah nilai-nilai spiritualitas, toleransi, solidaritas, kedisiplinan, kemandirian, kemajuan, dan keunggulan.

Lebih jauh lagi, ditransformasikan tantangan-tantangan yang akan dihadapi oleh Muhammadiyah, yaitu perkembangan dunia yang semakin kosmopolit. Perspektif kosmopolitanisme ini akan melahirkan relasi umat manusia yang semakin mendunia. Oleh karena itu, Muhammadiyah sebagai bagian integral dari warga semesta dituntut komitmennya untuk menyebarluaskan gerakan pencerahan bagi terbentuknya wawasan kemanusiaan universal yang menjunjung tinggi perdamaian, toleransi, kemajemukan, kebajikan, keadaban, dan nilainilai yang utama. Orientasi gerakan yang kosmopolitan tidak serta merta menjadikan Muhammadiyah kehilangan pijakan yang kokoh dalam ranah keindonesiaan dan kearifan lokal masyarakat NTT karena semua ini telah dipelajari oleh mahasiswa di dalam mata kuliah Pendidikan Multikultural.

Kompleksnya tantangan yang dihadapi di dalam menanamkan kemuhammadiyaan pada mahasiswa non-Muslim di UMK, maka di dalam pendidikan multilkultural di terapkan langkah-langkah pendekatan transformasi sebagai berikut: (1) Di dalam proses pembelajaran, dosen meyakinkan kepada mahasiswa non-Muslim adanya keberagaman peradaban, wawasan budaya, perundang- undangan, politik dan sistem sosial. (2) Dosen berupaya untuk meningkatkan strategi pembelajaran dengan menggunakan metode dialogis dengan cara membangun koalisi sosial yang masif di atas landasan sikap toleransi dan mahasiswa non-Muslim berkontribusi di dalam pembelajaran. (3) Dosen memiliki perhatian terhadap karya-karya tulis yang akan diberikan kepada mahasiswa non-Muslim dengan memfokuskan pada pembahasan tentang dalildalil aqli yang dikemukakan bersama teks-teks dalil syariat (Alquran dan Sunnah) (Kamal et al., 2018). (4) Proses pembelajaran lebih konsentrasi pada nilai-nilai positif dalam menjalin hubungan antara umat beragama di UMK, yaitu berlandaskan pada asal nenek moyang dan bertolak dari penghormatan Tuhan (Kamal et al., 2018). (5) Dosen berupaya untuk membangun kebersamaan dan menjunjung tinggi nilai-nilai multikulturalisme karena setiap peradaban terbagi-bagi sesuai dengan kebudayaannya, misalnya nilai keadilan, persamaan dan kebebasan. (6) Dalam pembelajaran ditekankan hak asasi manusia, yaitu perbedaan pandangan dan pemikiran di antaranya keberagaman agama, wawasan dan kebudayaan. Semua ini didukung karena menjadi dasar nilai-nilai di dalam Muhammadiyah.

\section{Menanamkan Kemuhammadiyaan melalui Pendekatan Aksi Sosial}

Pendekatan aksi sosial mengintegrasikan pendekatan transformasi dengan aktivitas nyata di dalam pembelajaran yang bertujuan untuk merangsang terjadinya proses perubahan sosial di dalam masyarakat NTT dan secara khusus di UMK. Setelah menerapkan pendekatan aksi sosial ini, beberapa mahasiswa menunjukkan respons yang kritis terhadap lingkungan kampus, layanan administrasi, dan proses perkuliahan, di antaranya dapat dilihat dari hasil wawancara berikut ini:

Pertama, respons mahasiswa terhadap layanan administrasi kampus UMK dapat dilihat dari hasil wawancara berikut,

saya melihat layanan administrasi di kampus UMK masih mengalami kendala, misalnya pengambil slip registrasi, KRU (Kartu Rencana Ujian) karena masih ada keterlibatan orang dalam. Mereka lebih 
diutamakan dari pada mahasiswa yang lain yang lebih dahulu menunggu antrian di BAAK. Hal ini tidak sesuai dengan aturan atau tata cara yang sudah dibuat oleh kampus UMK itu sendiri yang sudah melanggar atau tidak mencerminkan kampus yang bersifat Multikultural (S. S. Djou, personal communication, July 30 , 2019).

Layanan kampus yang harus diberikan kepada kami yang non-Muslim adalah kebebasan untuk membangun organisasi sesuai keyakinan atau agama kami, harus melayani kami non-Muslim sama seperti teman-teman dari agama Islam. Kampus juga kiranya menerima atau mengizinkan jika kami non-Muslim ingin melakukan suatu kegiatan pentas seni karena kami ingin kita semua yang ada di kampus UMK sama rata dalam arti semuanya sama tanpa ada pilih kasih (N. Y. Auw, personal communication, July 26, 2019).

Kedua, respons mahasiswa terhadap proses perkuliahan di UMK, dapat dilihat dari hasil wawancara berikut,

berdasarkan pengelaman saya, proses perkuliahan masih ada penindasanpenindasan kecil yang dilakukan oleh dosen terhadap mahasiswa. Ada dosen yang jarang masuk mengajar hanya menjual modul kepada mahasiswa dengan harga yang tinggi, ada dosen yang masuk hanya menjelaskan beberapa materi lalu menyuruh mahasiswa untuk mengkaji dan mencari tahu sendiri, ada dosen yang masuk hanya sibuk dengan dirinya sendiri setelah menyuruh mahasiswa berdiskusi, ada dosen yang tidak memberikan kesempatan kepada mahasiswa untuk bertanya dan mengemukakan pendapatnya. Setelah itu, dosen memberikan pertanyaan kepada kami, dan saya sendiri tidak berani untuk menjawab dan tidak berani untuk mengemukakan sebuah pendapat (M. Bisik, personal communication, August 5, 2019).

Di kampus UMK kebanyakan menyediakan para dosen yang menganut agama Islam dan terlalu sedikit dosen yang beragama non-Muslim, sehingga terkesan suasana dan lingkungan kampus yang Islamis (A. K. Nautu, personal communication, July 20, 2019).

Ketiga, respons mahasiswa terhadap lingkungan kampus UMK dapat dilihat dari hasil wawancara berikut,

lingkungan kampus UMK belum termasuk dalam nuansa multikultural karena lingkungan yang lebih mencirikan keislaman sehingga kami yang nonMuslim sedikit komplen terhadap suasana kampus. Misalnya, pengalaman saya di perpustakaan UMK, yaitu para pegawai yang berada di dalam perpustakaan semua menganut agama Islam sehingga lingkungan yang ada di dalam perpustakaan suasananya mencirikan keislaman (M. Bisik, personal communication, August 5, 2019).

Lingkungan kampus UMK masi kurang memungkinkan karena lingkungannya sempit, tidak ada tempat evakuasi, meskipun ada tempat parkir kendaraan tetapi tidak teratur dan tidak ada kantin, sehingga mahasiswa kebanyakan parkir dan duduk di luar lingkungan kampus seperti di jalan, teras pertokoan, dan warung makan. Selain itu, sampah berhamburan di mana-mana dan juga kolam air yang sangat kotor (S. S. Djou, personal communication, July 30, 2019).

Dari beberapa hasil wawancara di atas menunjukkan bahwa setelah diterapkan pendekatan aksis sosial di dalam mata kuliah Pendidikan Multikultural mahasiswa semikan kritis. Hasil-hasil kritik mahasiswa tersebut di atas adalah sebuah aksi sosial yang dapat dijadikan sebagai alasan perlunya perubahan sosial dan struktur di kampus UMK. Selain itu, di dalam pembelajaran ini juga, dosen menunjukkan kepedulian Muhammadiyah kepada masyarakat NTT yang non-Muslim. Misalnya, perdagangan manusia dan perlindungan buruh migran yang kebanyakan berasan dari NTT. Sehubungan dengan hal tersebut, Muhammadiyah melakukan advokasi secara serius terhadap para pekerja Indonesia di luar negeri dan memberikan wacana yang benar mengenai kesamaan derajat manusia. Muhammadiyah juga mengecam praktik perbudakan apapun bentuknya seperti yang 
terjadi pada korban human trafficking dan eksploitasi terhadap tenaga kerja serta menuntut pemerintah menindak tegas pelaku perdagangan dan eksploitasi terhadap orang-orang NTT.

\section{Strategi Dakwah Muhammadiyah pada Mahasiswa Non-Muslim dalam Pendidikan Multikultural}

Strategi dakwah Muhammadiyah di dalam pendidikan multikultural adalah sebuah transformasi kebodohan kepada pengetahuan, dari pengetahuan kepada ide, dan dari ide menuju gerakan, kemudian kepada tujuan yaitu ke-Tuhanan. Dakwah ini juga diartikan sebagai ajakan atau panggilan yang diarahkan pada mahasiswa non-Muslim untuk menerima kebaikan dan meninggalkan keburukan, atau perubahan dari suatu kondisi kepada kondisi yang lain yang lebih baik, atau dari suatu kondisi yang sudah baik kepada kondisi lain yang lebih baik lagi. Lebih jauh lagi, dakwah Muhammadiyah kepada mahasiswa nonMuslim adalah (1) seruan untuk berpikir, berdebat, dan berargumen dengan kebenaran (rasional-intelektual) karena dakwah bukan kegiatan indoktrinasi dan dogmatis. (2) Ajakan yang tujuannya dapat tercapai tanpa paksaan (persuasif), yaitu tidak ada paksaan bagi nonMuslim untuk memasuki agama Islam. Oleh karena itu, dakwah Muhammadiyah tidak hanya untuk menciptakan kesalehan pribadi, tetapi juga harus menciptakan kesalehan sosial (Kamal et al., 2018).

Strategi dakwah Muhammadiyah pada mahasiswa non-Muslim bersifat universal, komprehensif dan integral. Dakwah ini juga tidak hanya bersifat lisan dan tulisan tetapi sekaligus dakwah dengan perbuatan atau tindakan yang multiaspek yang diwujudkan dalam pendidikan multikultural. Oleh karena itu, ada dua upaya yang dilakukan untuk menerapkan dakwah kemuhammadiyaan pada mahasiswa non-Muslim di UMK, yaitu (1) upaya menerjemahkan nilai-nilai normatif Islam menjadi konsep-konsep yang operasional, dan (2) upaya menanamkan konsep-konsep kemuhammadiyaan dalam proses pembelajaran multikultural. Kedua upaya ini dimaksudkan untuk membuktikan kepada mahasiswa nonMuslim bahwa Islam benar-benar mampu untuk menjawab tantangan zaman, dan membuktikan bahwa Islam adalah agama yang kontekstual yaitu agama yang mampu menghadapi kondisi budaya yang berkembang dan hidup berdampingan dengan agama lainnya di dalam suatu lembaga pendidikan (Kamal et al., 2018). Ada dua strategi dakwah Muhammadiyah yang diterapkan oleh dosen dalam menanamkan kemuhammadiyaan pada mahasiswa nonMuslim di UMK, yaitu:

\section{Strategi Dakwah Kultural}

Strategi dakwah kultural yaitu menanamkan nilai-nilai kemuhammadiyaan pada mahasiswa non-Muslim dengan memperhatikan potensi dan kecenderungan mereka sebagai makhluk berkebudayaan, dalam rangka mewujudkan UMK sebagai kampus yang multikultural. Dakwah kultural Muhammadiyah yang diterapkan pada mahasiswa non-Muslim sama sekali tidak melegitimasikan hal-hal yang bertentangan dengan pemikiran Muhammadiyah karena dakwa ini merupakan penanaman kesadaran pluralitas beragama pada mahasiswa non-Muslim dalam rangka mewujudkan wawasan multikultural di UMK.

Dakwah kultural ini sifatnya universal sehingga tepat sasaran pada mahasiswa nonMuslim dalam menumbuhkan pikiran positif mereka terhadap agama Islam. Oleh karena itu, dapat dilakukan sebagai berikut: Pertama, nilai waktu, yaitu dosen menanamkan sikap disiplin waktu dengan cara memberikan penegasan pada mahasiswa akan pentingnya waktu. Dengan alasan bahwa di dalam lembaga Muhammadiyah manusia sebagai makhluk budaya, akan selalu rugi apabila tidak dapat memanfaatkan waktu dengan sebaik-baiknya.

Kedua, ilmu dan teknologi, yaitu dosen menyampaikan kepada mahasiswa bahwa Muhammadiyah menganjurkan kepada semua mahasiswa agar berilmu dan melandasi ilmunya dengan iman, sehingga derajatnya akan diangkat lebih tinggi daripada yang lain. Lebih jauh lagi, dosen menyampaikan bahwa Muhammadiyah menyuruh memperhatikan diri sendiri, memikirkan fenomena alam dan tentunya kemudian mahasiswa harus mengadakan penelitian, sehingga dapat menemukan rahasia-rahasia dan hukum-hukum yang terkandung di dalamnya, misalnya akan menghasilkan ilmu-ilmu sosial, kedokteran, psikologi, dan sebagainya. 
Ketiga, etos kerja, yaitu dosen menyampaikan kepada mahasiswa bahwa Muhammadiyah memandang manusia sebagai makhluk biologis yang penciptaannya terdiri dari unsur-unsur jasmaniah, unsur rohaniah serta akal pikiran, yang keseluruhannya merupakan suatu kesatuan yang utuh. Untuk kelangsungan dan kesempurnaan hidupnya, manusia membutuhkan konsumsi material, rohaniah dan akal. Oleh karena itu, manusia perlu memenuhi kebutuhan-kebutuhan itu khususnya kebutuhan material dengan cara manusia perlu kerja, dan karenanya Muhammadiyah memerintahkan agar manusia selalu memperhatikan kerjanya.

\section{Strategi Dakwah Komunitas}

Strategi dakwah komunitas merupakan bentuk aktualisasi dakwah Muhammadiyah yang diterapkan di UMK dengan perhatian atau fokus pada mahasiswa non-Muslim. Strategi ini yang lebih relevan untuk menghadapi mahasiswa non-Muslim yang lebih dominan dibandingkan mahasiswa Islam di UMK. Komunitas non-Muslim di UMK adalah sebuah kelompok sosial dari beberapa organisme dari berbagi lingkungan, umumnya memiliki ketertarikan dan tujuan yang sama. Komunitas non-Muslim di UMK secara individu memiliki maksud, kepercayaan, sumber daya, preferensi, kebutuhan, risiko, kegemaran, dan sejumlah kondisi lain yang serupa. Relasi dan pola hidup komunitas Muslin dan non-Muslim pada umumnya homogen, sehingga dapat dijumpai heterogenitas komunitas yang tumbuh dan berkembang di dalam lingkungan kampus UMK.

Prinsip dakwah pencerahan berbasis komunitas pada mahasiswa non-Muslim di UMK dapat dilihat sebagai berikut: (1) Dosen menerjemahkan pesan dan misi dakwah Muhammadiyah secara universal dan relevan yang membawa pencerahan dalam kehidupan komunitas non-Muslim di UMK. (2) Dosen mampu memahami dan memetakan komunitas non-Muslim secara lengkap sehingga tidak melahirkan diskriminasi. (3) Dosen mampu mengorganisasi/memobilisasi komunitas nonMuslim di UMK sehingga melahirkan pluralitas beragama. (4) Dosen mampu berinteraksi dan berkomunikasi sesuai dengan karakteristik komunitas non-Muslim untuk mengurangi inperioritas dan superioritas agama. (5) Dosen mampu membangkitkan solidaritas beragama di UMK yaitu terjalinnya hubungan harmonis antara mahasiswa Muslim dan non-Muslim sehingga dapat hidup rukun di dalam satu lingkungan, dan (6) dosen mampu mengembangkan proses pencerahan yang membebaskan, memberdayakan, dan memajukan kehidupan mahasiswa non-Muslim yang bermakna sesuai dengan nilai-nilai kemuhammadiyaan yang membawa kemajuan.

\section{Analisa Menanamkan Kemuhammadiyaan pada Mahasiswa Non-Muslim Melalui Pendidikan Multikultural.}

Menanamkan kemuhammadiyaan pada mahasiswa non-Muslim di dalam pendidikan multikultural melalui pendekatan kontribusi, aditif, transformasi dan aksi sosial dapat mewujudkan visi UMK yaitu wawasan multikultural. Manfaat yang diperoleh setelah menerapkan keempat pendekatan tersebut (J. A. Banks, 2017; Cole \& Zhou, 2014; Szelei et al., 2019), yaitu: Pertama, pendekatan kontribusi di dalam pendidikan multikultural adalah menanamkan kemuhammadiyaan pada mahasiswa non-Muslim bahwa agama di lingkungan kampus UMK dan di tempat lain sangat beragam, dan pada hakikatnya sebenarnya semua nilainya sama, yaitu samasama mengajarkan kebaikan, perdamaian, kehidupan dunia dan kehidupan setelah kematian serta penyembahan kepada Tuhan. Dengan demikian, mahasiswa non-Muslim mulai mengerti bahwa ada cara yang berbeda yang dilakukan oleh orang-orang Islam tetapi maksud dan nilainya sama dengan agama mereka (Barton, 2014). Sehingga setelah mereka belajar kemuhammadiyaan, mereka menerima perbedaan dengan proses rasa yang menyenangkan, dan pada akhirnya mahasiswa non-Muslim merasa bahwa perbedaan itu bukanlah masalah tetapi anugerah dari Tuhan.

Kedua, pendekatan aditif diterapkan di dalam pendidikan multikultural untuk menanamkan pengetahuan kemuhammadiyaan yang luas bagi mahasiswa non-Muslim. Oleh karena itu, pendekatan ini melahirkan rasa ketertarikan akan keragaman yang diperoleh di dalam pembelajaran multikultural dan dapat memotivasi mahasiswa non-Muslim untuk ingin tahu lebih banyak tentang 
Muhammadiyah. Wawasan yang luas tentang keragaman budaya, kehidupan, persahabatan, pengetahuan di dalam lingkungan kampus UMK maka mahasiswa non-Muslim akan tumbuh menjadi orang yang inklusif, mudah menerima yang berbeda, toleran dan menghargai orang lain (Muzayanah, 2017). Selain itu mudah berinteraksi dengan lingkungan yang baru ataupun yang kompleks.

Ketiga, pendekatan pembelajaran transformasi dapat melatih mahasiswa nonMuslim bersikap sportif terhadap kelebihan dan kekurangan baik dari diri sendiri maupun orang lain. Mahasiswa non-Muslim juga dilatih mampu menghargai, mengakui, dan mau mengambil hal-hal positif dari pembelajaran kemuhammadiyaan walaupun itu berbeda dengan ajaran agama mereka. Sehingga ini melahirkan proses transformasi agama dan pluralitas agama. Hal ini juga dapat melatih mahasiswa non-Muslim menjadi orang yang terbuka, positive thinking, dan berjiwa besar, sehingga tidak mudah berprasangka, menuduh, dan memberi label kafir pada agama lain (Hilmy, 2013).

Keempat, pendekatan aksi sosial bertujuan untuk menyiapkan mahasiswa nonMuslim memiliki pengetahuan, nilai, keterampilan bertindak dan berperan aktif dalam perubahan sosial, baik dalam skala regional, nasional, dan global. Dalam pendekatan ini, dosen berperan sebagai agent of social change (perubahan sosial) yang meningkatkan nilai-nilai demokratis, humanis, dan pluralis (Jung, 2014; Murtadlo, 2014).

Berdasarkan pada empat poin di atas Muhammadiyah menjunjung tinggi kemanusiaan universal tanpa memandang latar belakang etnis, agama, dan unsur primordial lain. Berpijak pada Sunnah Nabi, Muhammadiyah juga memandang bahwa golongan yang besar atau mayoritas harus selalu melindungi dan menyayangi yang kecil dan minoritas. Demikian pula sebaliknya, kelompok yang kecil atau minoritas harus menghormati yang besar dan mayoritas. Selain itu, berdasarkan sudut pandang sejarawan Kristiani, Sir Thomas Walker Arnold mengatakan bahwa Muhammad sendiri telah mengadakan satu kesepakatan dengan suku Kristian dan berjanji bertanggungjawab untuk melindungi mereka, beliau juga telah memberi kepada mereka kebebasan untuk mengerjakan syiar-syiar agama mereka dan memberi kebebasan kepada pegawai-pegawai gereja untuk melaksanakan ibadah dalam suasana aman dan tenteram (Kamal et al., 2018). Oleh karena itu, pendidikan multikultural di UMK selalu menjadi sebuah penengah dan pelindung terhadap mahasiswa non-Muslim di dalam proses pembelajaran. Muhammadiyah tidak pernah menerapkan paksaan dan intimidasi teologis pada mahasiswa non-Muslim. Muhammadiyah justru mengajarkan toleransi yang luhur dan pluralitas beragama pada mahasiswa non-Muslim melalui pendidikan multikultural (Banks, 2014).

Berdasarkan sudut pandang Kamal, pluralitas agama di UMK dapat diatasi dengan beberapa proposisi, yaitu: (1) Sebagai Muslim yang baik kita meyakini bahwa setiap manusia dari sudut pandang penciptaannya (ontologis) memiliki kemuliaan apapun ras, warna kulit, suku, dan agama. (2) Bersikap apresiatif terhadap pluralitas agama, karena perbedaan keyakinan merupakan sesuatu yang qodrati dari Tuhan, sehingga tidaklah mungkin bagi seorang Muslim melakukan intimidasi, pemaksaan, apalagi teror terhadap orang lain untuk masuk ke dalam Islam. (3) Memahami bahwa perintah dakwah dalam Islam adalah sebuah transformasi kepada kebaikan dan kebenaran, baik pada level pribadi dan masyarakat, dilakukan dengan cara persuasif dan komunikasi yang elegan, bukan indoktrinasi. (4) Pluralisme agama tidak bermakna kesediaan mengikuti ritual dan peribadatan di luar keyakinan masing-masing umat beragama, tetapi masing-masing pemeluk agama melakukan peribadatannya sesuai ajaran agamanya tanpa ada gangguan (Kamal et al., 2018; Santamaría, 2014).

Transformasi kemuhamadiyaan ke dalam pendidikan multikultural yang dilakukan di UMK dapat diketahui juga dari pemikiran dan sikap keberagamaan mahasiswa non-Muslim. Pemikiran bahwa dalam melaksanakan ajaran agama sesuai dengan konteksnya. Transformasi nilai-nilai Muhammadiyah inilah yang kemudian melahirkan mahasiswa non-Muslim yang berwatak (1) moderat namun konsisten terhadap agamanya masing-masing, (2) inklusif 
namun tetap menggunakan filter yang digunakan untuk memilah di dalam agamanya, (3) menghargai perbedaan namun bisa memosisikan diri dalam perbedaan tersebut secara jelas, (4) menghormati pemikiran dan bahkan keyakinan agama lain namun juga ada demarkasi yang jelas dalam masalah akidah (Ramadhan, 2015; Yang \& Montgomery, 2013).

\section{PENUTUP}

Menanamkan kemuhammadiayaan pada mahasiswa non-Muslim di UMK diterapkan melalui empat pendekatan pendidikan multikultural, yaitu pendekatan kontribusi, aditif, tranformasi dan aksi sosial. Keempat pendekatan ini dilakukan dengan maksud untuk menumbuhkan nilai-nilai kemuhammadiyaan pada mahasiswa non-Muslim dengan tidak melunturkan keyakinan mereka terhadap agamanya. Selain itu, pendidikan multikultural dapat memberikan solusi terhadap dakwah Muhammadiya di UMK dengan tetap mempertahankan gerakan Dakwah Amar Makruf Nahi Munkar agar dapat diterima olah mahasiswa non-Muslim sebagai pandangan hidup. Selain itu, pendekatan ini bertujuan untuk memberikan pemahaman kepada mahasiswa non-Muslim bahwa Muhammadiyah adalah sebuah organisasi Islam yang pro terhadap kemajemukan dan bersikap inklusif pada non-Muslim. Sementara itu, di dalam pembelajaran multikultural diterapkan strategi dakwah Muhammadiyah, yaitu dakwah kultural dan komunitas. Keduanya digunakan oleh dosen sebagai strategi pembelajaran untuk menjelaskan kemuhammadiyaan agar bisa diterima oleh mahasiswa non-Muslim. Dengan demikian, pendekatan pendidikan multikultural dan dakwah Muhammadiyah di dalam mata kuliah Pendidikan Multikultural tidak dimaksudkan untuk mengislamkan mahasiswa non-Muslim, tetapi pendidikan multikultural bertujuan untuk menumbuhkan sikap pluralis dan inklusif pada mahasiswa non-Muslim.

\section{DAFTAR PUSTAKA}

Altaş, N. (2015). Towards Comprehensive Religious Education (a Trial for New Research Ways within the Frame of Liberalism and Multiculturalism Concepts). Procedia - Social and
Behavioral Sciences, 174, 131-136. https://doi.org/10.1016/j.sbspro.2015.01. 637

Arifin, S. (2015). Rekonstruksi Al-Islam Kemuhammadiyahan (AIK) Perguruan Tinggi Muhammadiyah Sebagai Praksis Pendidikan Nilai. EDUKASI: Jurnal Penelitian Pendidikan Agama Dan Keagamaan, 13(2), 201-221. http://dx.doi.org/10.32729/edukasi.v13i2. 239

Auw, N. Y. (2019, July 26). Penrepan Pendidikan Multikultural (Syahrul, Interviewer) [Personal communication].

Banks, J. A. (2017). An Introduction to Multicultural Education. Pearson Education.

https://www.pearsonhighered.com/assets /preface/0/1/3/4/0134800362.pdf

Banks, James A. (2014). Diversity, Group Identity, and Citizenship Education in a Global Age. Journal of Education, 194(3), https://doi.org/10.1177/00220574141940 0302

Barton, G. (2014). The Gülen Movement, Muhammadiyah and Nahdlatul Ulama: Progressive Islamic Thought, Religious Philanthropy and Civil Society in Turkey and Indonesia. Islam and ChristianMuslim Relations, 25(3), 287-301. https://doi.org/10.1080/09596410.2014.9 16124

Bauman, S. S. M., Acker-Hocevar, M., Talbot, D. L., Visaya, A., Valencia, M., \& Ambriz, J. (2019). Exploring and Promoting the College Attendance and Success of Racial/Ethnic Minority Students. Journal of Multicultural Counseling and Development, 47(1), 3748. https://doi.org/10.1002/jmcd.12119

Berger, P. L., \& Luchmann. (2019). Tafsir Sosial Atas Kenyataan: Risalah Tentang Sosiologi Pengetahuan. LP3ES.

Bisik, M. (2019, August 5). Penerepan Pendidikan Multikultural (Syahrul, Interviewer) [Personal communication]. 
Cole, D., \& Zhou, J. (2014). Do Diversity Experiences Help College Students Become More Civically Minded? Applying Banks' Multicultural Education Framework. Innovative Higher Education, 39(2), 109-121. https://doi.org/10.1007/s10755-0139268-x

Creswell, J. W. (2013). Qualitative Inquiry and Research Design. SAGE Publication. https://books.google.co.id/books?id=Ykr uxor $10 \mathrm{cYC} \&$ printsec $=$ frontcover $\# \mathrm{v}=$ one page $\& \mathrm{q} \& \mathrm{f}=$ false

Demir, N., \& Yurdakul, B. (2015). The Examination of the Required Multicultural Education Characteristics in Curriculum Design. Procedia - Social and Behavioral Sciences, 174, 3651-3655. https://doi.org/10.1016/j.sbspro.2015.01. 1085

Djou, S. S. (2019, July 30). Penerapan Pendidikan Multikultural (Syahrul, Interviewer) [Personal communication].

Efendi, \& Suswanta. (2017). Politics of Education: Multiculturalism Practice in Universitas Muhammadiyah Kupang, NTT. Iseedu, 1(1), 47-72. https://doi.org/10.23917/iseedu.v1i1.542 0

Gökarıksel, B., \& Secor, A. (2015). Post-secular geographies and the problem of pluralism: Religion and everyday life in Istanbul, Turkey. Political Geography, 46, 21-30. https://doi.org/10.1016/j.polgeo.2014.10. 006

Gorski, P. C. (2009). What we're teaching teachers: An analysis of multicultural teacher education coursework syllabi. Teaching and Teacher Education, 25(2), 309-318. https://doi.org/10.1016/j.tate.2008.07.00 8

Hilmy, M. (2013). Whither Indonesia's Islamic Moderatism? A Reexamination on the Moderate Vision of Muhammadiyah and NU. Journal of Indoneia Islam, 7(1), 24 48-48. https://doi.org/10.15642/JIIS.2013.7.1.24 $-48$
Jung, E. (2014). Islamic Organizations and Electoral Politics in Indonesia: The Case of Muhammadiyah. South East Asia Research, 22(1), 73-86. https://doi.org/10.5367/sear.2014.0192

Kamal, F., Anshori, A., Hidayat, S., Anif, S., Waluyo, Muh., \& Damami, M. (2018). Tuntutan Tabligh. Majelis Tabligh Pimpinan Pusat Muhamamdiyah.

Mareş, P. (2014). Tolerance and Universalism. Procedia - Social and Behavioral Sciences, 149, 537-541. https://doi.org/10.1016/j.sbspro.2014.08. 206

Murtadlo, M. (2014). Pendidikan Multikultural di Madrasah Pembangunan Ciputat Tangerang. EDUKASI: Jurnal Penelitian Pendidikan Agama Dan Keagamaan, 12(2), 196-209. http://dx.doi.org/10.32729/edukasi.v12i2. 82

Muzayanah, U. (2017). Indeks Pendidikan Multikultural dan Toleransi Siswa SMA/K di Gunungkidul dan Kulonprogo. EDUKASI: Jurnal Penelitian Pendidikan Agama Dan Keagamaan, 15(2), 223-240. http://dx.doi.org/10.32729/edukasi.v15i2. 309

Nautu, A. K. (2019, July 20). Penerapan Pendidikan Multkultural (Syahrul, Interviewer) [Personal communication].

Nelson, B. (2019, July 29). Penerapan Pendidikan Multikultural (Syahrul, Interviewer) [Personal communication].

Nubatonis, F. (2019, July 29). Penerapan Pendidikan Multikultural (Syahrul, Interviewer) [Personal communication].

Paul-Binyamin, I., \& Haj-Yehia, K. (2019). Multicultural education in teacher education: Shared experience and awareness of power relations as a prerequisite for conflictual identities dialogue in Israel. Teaching and Teacher Education, 85, 249-259. https://doi.org/10.1016/j.tate.2019.06.02 1 
Ramadhan, M. (2015). Deradikalisasi Agama Melalui Pendidikan Multikultural dan Inklusivisme (Studi pada Pesantren alHikmah Benda Sirampog Brebes). SMART, 1(2). https://doi.org/10.18784/smart.v1i2.250

Santamaría, L. J. (2014). Critical Change for the Greater Good: Multicultural Perceptions in Educational Leadership Toward Social Justice and Equity. Educational Administration Quarterly, 50(3), 347391.

https://doi.org/10.1177/0013161X13505 287

Savage, C. (2019). Academic majors of social studies teachers and student achievement in the U.S. Teaching and Teacher Education, 84, 66-73. https://doi.org/10.1016/j.tate.2019.04.02 0

Schoorman, D., \& Bogotch, I. (2010). Conceptualisations of multicultural education among teachers: Implications for practice in universities and schools. Teaching and Teacher Education, 26(4), 1041-1048.

https://doi.org/10.1016/j.tate.2009.10.04 7

Syamsuddin, M. (2018). Gerakan Muhammadiyah dalam Membumikan Wacana Multikulturalisme: Sebuah Landasan Normatif-Institusional. Jurnal Pemberdayaan Masyarakat: Media Pemikiran dan Dakwah Pembangunan, 1(2), 361. https://doi.org/10.14421/jpm.2017.01208
Szelei, N., Tinoca, L., \& Pinho, A. S. (2019). Rethinking 'cultural activities': An examination of how teachers utilised student voice as a pedagogical tool in multicultural schools. Teaching and Teacher Education, 79, 176-187. https://doi.org/10.1016/j.tate.2018.12.02 0

Wibowo, A. M. (2018). Multikulturalisme Peserta Didik Muslim di Yogyakarta. EDUKASI: Jurnal Penelitian Pendidikan Agama Dan Keagamaan, 16(1), 35-49. http://dx.doi.org/10.32729/edukasi.v16i1. 457

Wula, Z. (2019, June 15). Penerapan Pendidikan Multikultural (Syahrul, Interviewer) [Personal communication].

Yang, Y., \& Montgomery, D. (2013). Gaps or bridges in multicultural teacher education: A Q study of attitudes toward student diversity. Teaching and Teacher Education, 30, 27-37. https://doi.org/10.1016/j.tate.2012.10.00 3 